\title{
Valuing Coca-Cola And Pepsico Options Using The Black-Scholes Option Pricing Model And Data Downloads From The Internet
}

John C. Gardner, University of New Orleans, USA

Carl B. McGowan, Jr., Norfolk State University, USA

\begin{abstract}
In this paper, we demonstrate how to collect the data and compute the actual value of BlackScholes Option Pricing Model call option prices for Coca-Cola and PepsiCo. The data for the current stock price and option price are taken from Yahoo Finance and the daily returns variance is computed from daily prices. The time to maturity is computed as the number of days remaining for the stock option. The risk-free rate is obtained from the U.S. Treasury website.
\end{abstract}

Keywords: Black-Scholes Option Pricing Model; Coca-Cola; PepsiCo; Options Data; Returns Data; Treasury Bill Rates

\section{INTRODUCTION}

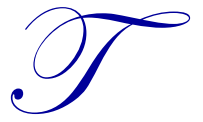

he objective of this paper is to demonstrate how to calculate the value of a call option using the Black-Scholes Option Pricing Model (1973) for two actual companies: Coca-Cola (KO) and Pepsico (PEP). We discuss the BSOPM and how to collect the data from internet sources to value call options for KO and PEP. The five input variables for the BSOPM are the price of the underlying stock, the instantaneous variance of the underlying stock, the time to expiration of the call option, the risk-free rate of return, and the exercise price of the underlying stock [Black and Scholes (1973, page 639]. The price of the underlying stock, the time to expiration of the call option and the exercise price of the underlying stock are found using Yahoo Finance. The instantaneous variance of the underlying stock is computed using daily return data for both companies taken from Yahoo Finance. The risk-free rate of return is taken from the U.S. Treasury website.

\section{The Black-Scholes Option Pricing Model}

A call option gives the owner of the option the right to purchase shares of a stock at a pre-determined price called the exercise price, Black and Scholes (1973, page 637). Conversely, the issuer of the call option has the obligation to sell shares to the buyer of the option at the pre-determined price if the owner exercises the option. The owner of the call option believes the price of the stock will increase while the issuer of the option believes that the stock price will not increase. If the stock price increases, the call owner will profit from the stock price increase if the ending stock price is above the exercise price. Conversely, the issuer of the option will lose money if the stock price increases more than the value of the premium received.

The value of a call option is the current price of the stock minus the present value of the exercise price if future values are known with certainty, Kolb (1991).

$\mathbf{V}=\mathbf{P}-\mathbf{X e}^{-\mathrm{rt}}$

The value of the call option is V. The current selling price of the optioned stock is $\mathrm{P}$. The exercise price of the call option for the optioned stock is $\mathrm{X}$, the risk-free rate of return is $\mathrm{r}$, and the time to expiration is the ratio of the 
number of days to expirations divided by 365 , t. Under conditions of certainty, the call option value is the current stock price minus the present value of the exercise price.

The Black-Scholes (1973) Option Pricing Model, for which Myron S. Scholes received the The Sveriges Riksbank Prize in Economic Sciences in Memory of Alfred Nobel 1997 along with Robert C. Merton for his work with Fischer developing the Option Pricing Model, adjusts for risk with two risk variables. $N\left(d_{1}\right)$ is the risk adjustment factor applied to the current stock price for risk and $\mathrm{N}\left(\mathrm{d}_{2}\right)$ is the risk adjustment factor applied to the present value of the exercise price.

$$
\mathbf{V}=[\mathbf{P}] *\left[\mathbf{N}\left(\mathbf{d}_{1}\right)\right]-[\mathbf{X}]^{*}\left[\mathrm{e}^{-\mathrm{rt}}\right] *\left[\mathbf{N}\left(\mathbf{d}_{2}\right)\right]
$$

where,

$$
\begin{aligned}
& {[\ln (\mathbf{P} / \mathbf{X})]+[\mathbf{r}+\operatorname{var} / 2] *[\mathbf{t}]} \\
& d_{1}= \\
& d_{2}=\left[d_{1}\right]-[s t d] *[t]^{1 / 2} \\
& {[\ln (\mathbf{P} / \mathbf{X})]+[\mathbf{r}+\operatorname{var} / 2]^{*}[\mathbf{t}]-[\operatorname{var}] *[\mathbf{t}]} \\
& d_{2}=
\end{aligned}
$$

The instantaneous variance of the probability distribution of the optioned stock is var, the standard deviation of the probability distribution of the optioned stock is std, and the natural logarithm operator is $\ln . \mathrm{N}(:)$ is the cumulative normal density function of the expression (:) and is the probability that an outcome will be as great as the calculated value or greater [Black and Scholes (1973, page 639)].

The underlying assumptions of the BSOPM are that the short term interest rate is known and constant, the price of the optioned stock is lognormal, the stock does not pay dividends, the option can only be exercised at maturity, there are no transaction costs, and short selling is permitted [Black and Scholes (1973, page 640)]. Thus, using the BSOPM, the value of the call option can be calculated using the following information:

1. the price of the optioned stock,

2. the instantaneous volatility of the optioned stock,

3. the time to expiration of the call option measured as portion of a year,

4. the risk-free rate of return, and

5. the exercise price for the optioned stock.

The value of the call option is directly related to variables 1 to 4 and inversely related to variable 5 . For example, if the price of the optioned stock increases, the value of the call option increases. If the exercise price of the underlying optioned stock increases, the value of the call option decreases.

\section{DATA COLLECTION}

The current price of the stock and the current price of the option are found on the company page for $\mathrm{KO}$ or PEP on Yahoo Finance which lists the current price for options at various strike prices. Go to Yahoo Finance and enter the ticker symbol for the stock in the Get Quotes box and press enter. The data page for the company (KO) will come on the screen as shown in Figure 1. Click the Options cell and the current prices, exercise prices, and expiration dates will come on the screen as shown in Figure 2. We compute the value of call options for KO and PEP for $11 / 23 / 2010$. The instantaneous variance is computed using one year of daily returns derived from the Historical Prices function on Yahoo! Finance, as shown in Figure 3. Enter the beginning and ending dates for the previous year in the Set Data Range boxes. Click the Get Prices cell and then move to the bottom of the page and click the Download to Spreadsheet cell. The data for daily prices can be downloaded to a spreadsheet and daily returns can be calculated. The instantaneous variance used in the BSOPM is the variance of daily returns for the year of daily returns. 


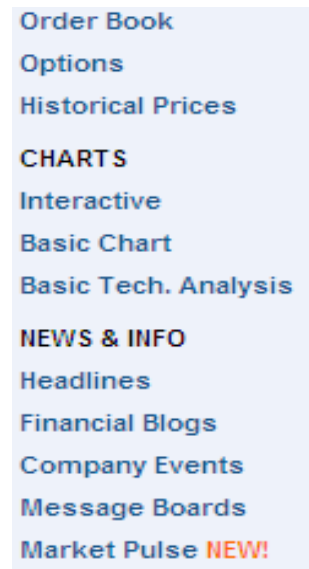

Order Book

Prices

Basic Tech. Analysis

NEWS \& INFO

Headlines

Financial Blogs

Company Events

Market Pulse NEW!

\section{Coca-Cola Company (The) Common (NYSE: KO) \\ REAL-TIME $68.40 \Downarrow 1.28(1.84 \%)$ 1:30PM EDT}

\begin{tabular}{|c|c|c|c|}
\hline Last Trade: & 68.42 & Day's Range: & $67.77-69.60$ \\
\hline Trade Time: & 12:58PM EDT & 52wk Range: & $54.97-69.82$ \\
\hline Change: & $1.26(1.81 \%)$ & Volume: & $6,743,822$ \\
\hline Prev Close: & 69.68 & Avg Vol (3m): & $9,868,670$ \\
\hline Open: & 69.60 & Market Cap: & 157.10B \\
\hline Bid: & $68.42 \times 300$ & $\mathrm{P} / \mathrm{E}(\mathrm{ttm})$ : & 12.74 \\
\hline Ask: & $68.43 \times 1000$ & EPS (ttm): & 5.37 \\
\hline 1y Target Est: & 76.29 & Div \& Yield: & $1.88(2.70 \%)$ \\
\hline
\end{tabular}

Figure 1: Yahoo Finance Page for KO

http://finance.yahoo.com/q?s=ko\&ql=1

\section{Options}

View By Expiration: Sep 11 | Oct 11 | Nov 11 | Jan 12 | Feb 12 | Jan 13

\begin{tabular}{|c|c|c|c|c|c|c|c|}
\hline \multicolumn{4}{|c|}{ Call Options } & \multicolumn{4}{|c|}{ Expire at close Friday, September 16, 2011} \\
\hline Strike & Symbol & Last & Chg & Bid & Ask & Vol & Open Int \\
\hline 60.00 & KO110917C00060000 & 8.20 & $\downarrow 1.40$ & 8.55 & 8.65 & 16 & 60 \\
\hline 62.50 & KO110917C00062500 & 6.05 & $\downarrow 0.42$ & 6.20 & 6.30 & 23 & 388 \\
\hline 65.00 & KO110917C00065000 & 3.65 & $\downarrow 1.35$ & 4.00 & 4.10 & 112 & 3,785 \\
\hline 67.50 & KO110917C00067500 & 2.12 & $\$ 0.75$ & 2.12 & 2.16 & 754 & 19,266 \\
\hline 70.00 & KO110917C00070000 & 0.80 & $\downarrow 0.40$ & 0.79 & 0.81 & 763 & 14,735 \\
\hline 72.50 & KO110917C00072500 & 0.16 & $\downarrow 0.14$ & 0.18 & 0.19 & 386 & 5,534 \\
\hline 75.00 & KO110917C00075000 & 0.02 & $\downarrow 0.03$ & 0.02 & 0.03 & 3 & 206 \\
\hline
\end{tabular}

Figure 2: Yahoo Finance Page for KO Options (Current Price, Exercise Price, And Days To Maturity)

http://finance.yahoo.com/q/op?s=KO+Options

\section{Historical Prices}

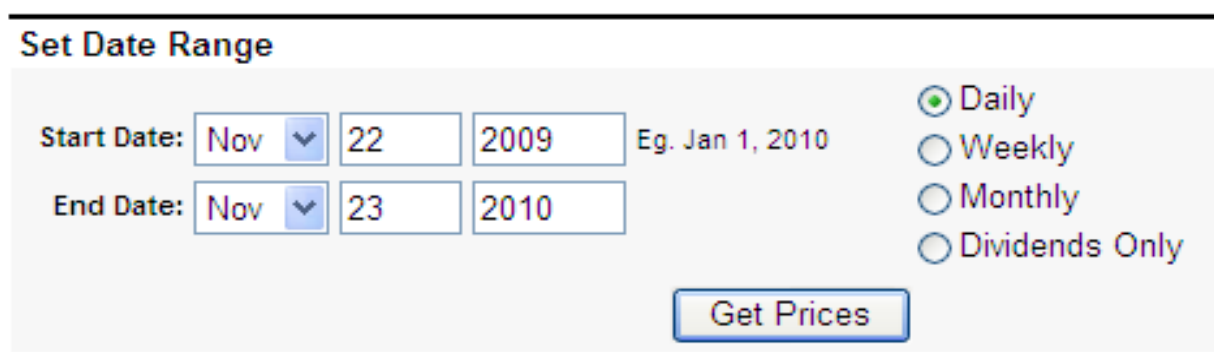

Figure 3: Yahoo Finance Page for stock prices for KO http://finance.yahoo.com/q/hp?s=KO+Historical+Prices 
The risk-free rate of return is taken from the US Department of the Treasury website, http://www.treasury.gov/resource-center/data-chart-center/interestrates/Pages/TextView.aspx?data=billRatesYear\&year $=2010$. The time to maturity is calculated as the number of days remaining until expiration of the option divided by 365 - the number of days in a year.

\section{Resource Center}

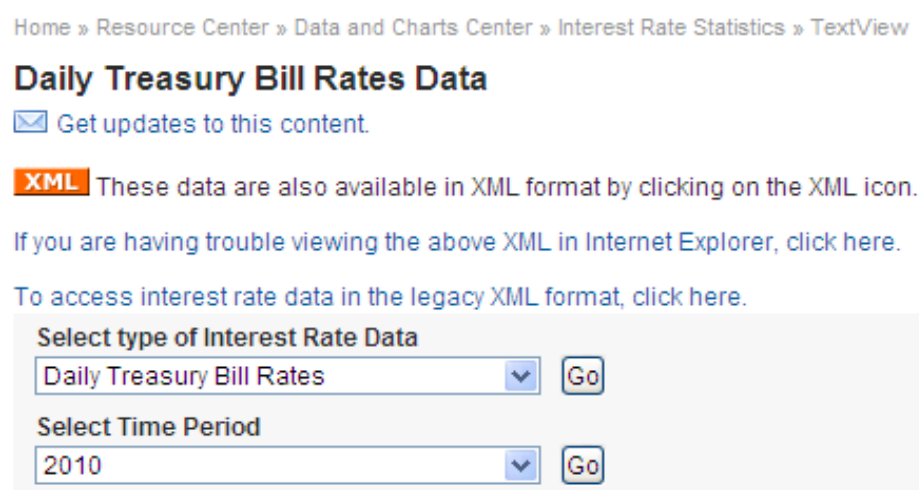

\section{Daily Treasury Bill Rates Data}

$\square$ Get updates to this content.

XML These data are also available in XML format by clicking on the XML icon.

If you are having trouble viewing the above XML in Internet Explorer, click here.

To access interest rate data in the legacy XML format, click here.

Select type of Interest Rate Data

Daily Treasury Bill Rates $\checkmark$ Go

Select Time Period

$2010 \quad \checkmark$ Go

\begin{tabular}{|c|c|c|c|c|c|c|c|c|}
\hline & 4 WEEKS & & 13 WEEKS & & 26 WEEKS & & 52 WEEKS & \\
\hline DATE & $\begin{array}{l}\text { BANK } \\
\text { DISCOUNT }\end{array}$ & $\begin{array}{l}\text { COUPON } \\
\text { EQUIVALENT }\end{array}$ & $\begin{array}{l}\text { BANK } \\
\text { DISCOUNT }\end{array}$ & $\begin{array}{l}\text { COUPON } \\
\text { EQUIVALENT }\end{array}$ & $\begin{array}{l}\text { BANK } \\
\text { DISCOUNT }\end{array}$ & $\begin{array}{l}\text { COUPON } \\
\text { EQUIVALENT }\end{array}$ & $\begin{array}{l}\text { BANK } \\
\text { DISCOUNT }\end{array}$ & $\begin{array}{l}\text { COUPON } \\
\text { EQUIVALENT }\end{array}$ \\
\hline $01 / 04 / 10$ & 0.05 & 0.05 & 0.08 & 0.08 & 0.18 & 0.18 & 0.41 & 0.42 \\
\hline $01 / 05 / 10$ & 0.03 & 0.03 & 0.07 & 0.07 & 0.17 & 0.17 & 0.37 & 0.38 \\
\hline
\end{tabular}

Figure 4: US Department of the Treasury Resource Center

\section{Calculating The Value Of An Option}

Table 1 (KO) and Table 2 (PEP) show how to calculate the value of a call option using the Black-Scholes option pricing model for KO and PEP, Equation [2]. The Excel function normsdist(n) determines the cumulative normal distribution values. This function is used to calculate the values of $\mathrm{N}\left(\mathrm{d}_{1}\right)$, Equation [2], and $\mathrm{N}\left(\mathrm{d}_{2}\right)$, Equation[3]. Panel 1 of each table contains the input values for each of the five input variables needed to calculate the value of an option: the price of the underlying common stock, $\mathrm{P}$; the exercise price of the option, $\mathrm{X}$; the risk-free rate of interest, $\mathrm{r}$; the time to expiration, expressed as the proportion of a year, $t$; and the variance of the underlying stock return, var. Panel 2 of each table contains the values of a call option on this stock. Panel 3 of each table shows the values needed to calculate $d_{1}, d_{2}$, $\mathrm{N}\left(\mathrm{d}_{1}\right)$ and $\mathrm{N}\left(\mathrm{d}_{2}\right)$.

Table 1 for $\mathrm{KO}$ is the spreadsheet showing how to calculate the value of a call for Coca-Cola. The market price of $\mathrm{KO}$ is $\$ 61.67$, the exercise price of the option is $\$ 50$, the risk-free rate of interest is 0.26 percent, the time to expiration of the option is 19 days, and the instantaneous variance of the stock returns is 0.000096. Based on these numbers, the value of a call option on this stock is $\$ 11.68$.

Table 2 for PEP is the spreadsheet showing how to calculate the value of a call for Pepsi. The market price of PEP is $\$ 62.98$, the exercise price of the option is $\$ 60$, the risk-free rate of interest is 0.26 percent, the time to expiration of the option is 19 days, and the instantaneous variance of the stock returns is 0.009893 . Based on these numbers, the value of a call option on this stock is $\$ 2.99$. 
Table 1: The Black-Sholes Option Pricing Model Calculation - COKE

\begin{tabular}{|c|c|c|}
\hline Input Values & Value & \\
\hline Current price of stock & 61.67 & $11 / 23 / 2010$ \\
\hline Exercise price of option(strike price) & 50.00 & $11 / 23 / 2010$ \\
\hline Risk-free rate of interest & 0.26 & \\
\hline Time to expiration & 24 & Expire 12-10-10 \\
\hline \multirow[t]{2}{*}{ Variance of stock return $=\mathrm{s}^{\wedge} 2$} & 0.000096056 & \\
\hline & 0.009800794 & \\
\hline \multicolumn{3}{|l|}{ Calculated Values: } \\
\hline $\ln (\mathrm{P} / \mathrm{X})$ & 0.240904881 & \\
\hline$\left[\left(\mathrm{s}^{\wedge} 2\right) / 2\right]$ & 0.000048028 & \\
\hline$\left[\mathrm{R}+\left(\mathrm{s}^{\wedge} 2\right) / 2\right]$ & 0.260048028 & \\
\hline$\left[\mathrm{R}+\left(\mathrm{s}^{\wedge} 2\right) / 2\right] *[\mathrm{t}]$ & 0.017099048 & \\
\hline $\ln (\mathrm{P} / \mathrm{X})+\left[\mathrm{R}+\left(\mathrm{s}^{\wedge} 2\right) / 2\right] *[\mathrm{t}]$ & 0.258003929 & \\
\hline $\mathrm{s}$ & 0.009800794 & \\
\hline $\mathrm{t}^{\wedge}(.5)$ & 0.128212153 & \\
\hline $\mathrm{s} * \mathrm{t}^{\wedge}(.5)$ & 0.001256581 & \\
\hline $\mathrm{e}^{\wedge}(-\mathrm{rt})$ & 0.999829056 & \\
\hline $\mathrm{d} 1=$ & 90.27 & \\
\hline $\mathrm{d} 2=$ & 90.27 & \\
\hline $\mathrm{N}(\mathrm{d} 1)=$ & 1.0000 & \\
\hline $\mathrm{N}(\mathrm{d} 2)=$ & 1.0000 & \\
\hline Call Value & 11.68 & \\
\hline
\end{tabular}

Table 2: The Black-Sholes Option Pricing Model Calculation - PEPSI

\begin{tabular}{|c|c|c|}
\hline Input Values & Value & \\
\hline Current price of stock $(\mathrm{P})$ & 62.98 & $11 / 23 / 2010$ \\
\hline Exercise price of option(strike price)(x) & 60.00 & $11 / 23 / 2010$ \\
\hline Risk free rate of interest $\%$ & 0.26 & \\
\hline Time to expiration $(\mathrm{t})$ & 19 & Expire12-17-2010 \\
\hline \multirow[t]{2}{*}{ Variance of stock returns $=\mathrm{s}^{\wedge} 2$} & 0.00009669 & \\
\hline & 0.00983293 & \\
\hline \multicolumn{3}{|l|}{ Calculated Values: } \\
\hline $\ln (\mathrm{P} / \mathrm{X})$ & 0.06281829 & \\
\hline$\left[\left(\mathrm{s}^{\wedge} 2\right) / 2\right]$ & 0.00004834 & \\
\hline$\left[\mathrm{R}+\left(\mathrm{s}^{\wedge} 2\right) / 2\right]$ & 0.26004834 & \\
\hline$\left[\mathrm{R}+\left(\mathrm{s}^{\wedge} 2\right) / 2\right]^{*}[\mathrm{t}]$ & 0.01709907 & \\
\hline $\ln (\mathrm{P} / \mathrm{X})+\left[\mathrm{R}+\left(\mathrm{s}^{\wedge} 2\right) / 2\right] *[\mathrm{t}]$ & 0.07991736 & \\
\hline s & 0.00983293 & \\
\hline $\mathrm{t}^{\wedge}(.5)$ & 0.11407760 & \\
\hline $\mathrm{s}^{*} \mathrm{t} \wedge(.5)$ & 0.00112172 & \\
\hline $\mathrm{e}^{\wedge}(-\mathrm{rt})$ & 0.99986467 & \\
\hline $\mathrm{d} 1=$ & 26.01 & \\
\hline $\mathrm{d} 2=$ & 26.01 & \\
\hline $\mathrm{N}(\mathrm{d} 1)=$ & 1.00000000 & \\
\hline $\mathrm{N}(\mathrm{d} 2)=$ & 1.00000000 & \\
\hline Call Value & 2.99 & \\
\hline
\end{tabular}




\section{AUTHOR INFORMATION}

John C. Gardner is the KPMG Professor of Accounting in the Department of Accounting at the University of New Orleans. He earned his undergraduate degree in accounting from SUNY at Albany, and MBA and Ph.D. degrees in finance from Michigan State University. Dr. Gardner has published in leading accounting, finance and management science journals including The Accounting Review, Journal of Accounting Research, Contemporary Accounting Research, Accounting, Organizations and Society, Journal of Financial and Quantitative Analysis and Decision Sciences. His research interests include multi-national corporation financial management, capital structure, and financial and forensic accounting.

Carl B. McGowan, Jr., PhD, CFA is a Faculty Distinguished Professor and Professor of Finance at Norfolk State University, has a BA in International Relations (Syracuse), an MBA in Finance (Eastern Michigan), and a PhD in Business Administration (Finance) from Michigan State. From 2003 to 2004, he held the RHB Bank Distinguished Chair in Finance at the Universiti Kebangsaan Malaysia and has taught in Cost Rica, Malaysia, Moscow, Saudi Arabia, and The UAE. Professor McGowan has published in numerous journals including American Journal of Business Education, Applied Financial Economics, Decision Science, Financial Practice and Education, The Financial Review, International Business and Economics Research Journal, The International Review of Financial Analysis, The Journal of Applied Business Research, The Journal of Business Case Studies, The Journal of Diversity Management, The Journal of Real Estate Research, Managerial Finance, Managing Global Transitions, The Southwestern Economic Review, and Urban Studies. E-mail: cbmcgowan@nsu.edu (Corresponding author)

\section{REFERENCES}

1. Black, Fischer and Myron Scholes. "The Pricing of Options and Corporate Liabilities," Journal of Political Economy, (May-June 1973): pp. 637-654.

2. $\quad$ Kolb, Robert W. Options: An Introduction, (Kolb Publishing: Miami), 1991.

3. $\quad$ Quist Valuation News, volume 3, number 1, 2006, page 4-5.

4. $\quad$ http://finance.yahoo.com/q?s=ko\&ql=1

5. http://finance.yahoo.com/q/hp?s=KO+Historical+Prices

6. http://finance.yahoo.com/q/op?s=KO+Options

7. http://www.treasury.gov/resource-center/data-chart-center/interest$\underline{\text { rates} / \text { Pages/TextView.aspx } \text { ?data=billRates Year\&year }=2010}$ 